\title{
PENINGKATAN HASIL BELAJAR IPA TENTANG EKOSISTEM MELALUI METODE PROBLEM BASED LEARNING PADA SISWA KELAS V SEKOLAH DASAR KABUPATEN TANA TIDUNG
}

\author{
Yulis Suwandi \\ Guru Sekolah Dasar 009 Sesayap \\ julissuwandi@gmail.com
}

\begin{abstract}
The purpose of this study was to obtain empirical data on the use of learning methods Problem Based Learning (PBL) in improving learning outcomes Natural Sciences on the ecosystem. This study was conducted in primary schools to research subjects fifth grade students totaling 30 people. This research is an action using a model Kemmis and McTaggart, conducted in two cycles. The results showed an increase in the value of this is evidenced by the Natural Sciences learning outcomes of students in the first cycle is $60 \%$ of students who tuntasdengan average grade 68 , increased in the second cycle at $90 \%$ of students who completed with an average grade teachers 78 . Activities and students according to the steps of this method reach 100\% (mastery learning) at the end of the second cycle. The conclusion of this study indicate that the use of methods Problem Based Learning (PBL) can improve learning outcomes Natural Sciences.
\end{abstract}

Keyword: Learning Outcomes Natural Sciences, Methods Of Problem Based Learning (PBL), Ecosystems

\begin{abstract}
Abstrak: Tujuan penelitian ini adalah untuk memperoleh data empirik tentang pemanfaatan metode pembelajaran Problem Based Learning (PBL) dalam meningkatkan hasil belajar IPA tentang ekosistem. Penelitian ini dilaksanakan di Sekolah Dasar yang dengan subjek penelitian siswa kelas V yang berjumlah 30 orang. Penelitian ini merupakan penelitian tindakan dengan menggunakan model Kemmis dan McTaggart, dilakukan dalam dua siklus. Hasil penelitian menunjukkan adanya peningkatan hal ini dibuktikan dengan nilai hasil belajar Ilmu Pengetahuan Alam siswa pada siklus I yaitu 60\% siswa yang tuntasdengan rata-rata kelas 68 , meningkat pada siklus II mencapai $90 \%$ siswa yang tuntas dengan rata-rata kelas 78. Aktivitas guru dan siswa sesuai langkah-langkah metode ini mencapai 100\% (mastery learning) pada akhir siklus II. Kesimpulan dari penelitian ini menunjukkan bahwa penggunaan metode Problem Based Learning (PBL) dapat meningkatkan hasil belajar Ilmu Pengetahuan Alam.
\end{abstract}

Kata kunci: Hasil Belajar Ilmu Pengetahuan Alam, Metode Problem Based Learning (PBL), Ekosistem 
Pendidikan merupakan salah satu faktor utama bagi pengembangan sumber daya manusia, karena pendidikan diyakini mampu meningkatkan sumber daya manusia sehingga dapat menciptakan manusia produktif yang mampu memajukan bangsanya. Dalam proses pendidikan di sekolah, kegiatan belajar merupakan kegiatan yang paling utama. Tantangan pendidikan saat ini adalah menciptakan mutu pendidikan yang berkualitas.

Mutu pendidikan merupakan tantangan utama dalam perkembangan globalisasi saat ini. Menurut Sri Wuryastuti dalam Haryono (2013: 1), sudah lama orang menyadari dan mempertimbangkan tentang rendahnya mutu pendidikan IPA. Diantaranya indikator yang digunakan untuk menunjukkan rendahnya mutu pendidikan IPA adalah laporan United Nation Development Project (UNDP) yang menunjukkan bahwa dalam Human Development Index (HDI), Indonesia menduduki peringkat ke 110 diantara berbagai Negara di dunia.

Dengan kondisi tersebut guru dapat melakukan penelitian tindakan kelas untuk memperbaiki praktek pembelajaran yang dilakukan menjadi lebih berkuali tas dan lebih efektif. Menurut Suharmi yang dikutip Mohammad Asrori (2012:5) mendefinisikan penelitian tindakan kelas adalah suatu pencermatan terhadap kegiatan belajar berupa sebuah tindakan, yang sengaja dimunculkan dan terjadi dalam sebuah kelas secara bersama. Tindakan tersebut diberikan oleh guru yang dilakukan oleh siswa.

Dalam konteks tujuan penelitian tindakan kelas ini, secara rinci Suharjo mengemukakan (2012:13-14) sebagai berikut: 1) Meningkatkan mutui isi, masukan, proses, serta hasil pendidikan dan pembelajaran di sekolah. 2) Membantu guru dan tenaga kependidikan lainnya mengatasi masalah pembelajaran dan pendidikan di dalam kelas. 3) Meningkatkan sikap profesional pendidik dan tenaga kependidikan. 4) Menumbuh-kembangkan budaya akademik di lingkungan sekolah sehingga tercipta sikap pro aktif di dalam melakukan perbaikan mutu pendidikan dan pembelajaran secara berkelanjutan (sustainable).

Harold spears yang dikutip Siregar dan Hartini Nara (2010:4) mendeskripsikan pengertian, Blearning is to observe, to read, to imitate, to try somethingthem selves, to listen, to follow direction. Gagne yang dikutip Wahab Jufri (2013:58) menjelaskan hasil belajar adalah kemampuan (ferformance) yang dapat teramati dalam diri seseorang dan di sebut kapabilitas. Usman yang dikutip Asep Jihad dan Abdul (2012:14) menyatakan bahwa hasil belajar yang dicapai oleh siswa sangat erat kaitannya dengan 
rumusan tujuan instruksional yang direncanakan guru sebelumnya yang dikelompokkan kedalam tiga katogori, yakni domain kognitif, afektif, dan psikomotor.

Menurut Ngalimun (2014:89) PBL adalah suatu model pembelajaran yang melibatkan siswa untuk memecahkan suatu masalah melalui tahap-tahap metode ilmiah sehingga siswa dapat mempelajari pengetahuan yang berhubungan dengan masalah tersebut dan sekaligus memiliki keterampilan untuk memecahkan masalah. Abidin (2013:163-165) menjelaskan langkahlangkah PBL yaitu Prapembelajaran, Fase 1: menemukan masalah, Fase 2: Membangun Struktur Kerja, Fase 3: menetapkan masalah, Fase 4: mengumpulkan dan berbagai informasi, Fase 5: merumuskan solusi, Fase 6: menentukan solusi terbaik,Fase 7: menyajikan solusi, Pasca Pembelajaran.

Penelitian yang dilakukan adalah penelitian tindakan kelas (Classroom Action research) dengan model Kemmis and $\mathrm{Mc}$ Taggart, dimana alternatif tindakan yang dipilih adalah metode Problem Based Learning (PBL), sebagai upaya untuk meningkatkan hasil belajar siswa tentang ekosistem pada pembelajaran hubungan mnakhluk hidup dalam ekosistem dalam lingkungan sekolah, rumah dan masyarakat siswa kelas V SDN 009 Sesayap Kabupaten Tana Tidung.

\section{METODE}

Tujuan penelitian ini adalah untuk memperoleh data empirik tentang pemanfaatan model pembelajaran Problem Based Learning (PBL) dalam meningkatkan hasil belajar siswa SDN 009 Sesayap pada pembelajaran IPA tentang ekosistem pada pembelajaran hubungan makhluk hidup dalam ekosistem.

Penelitian ini merupakan penelitian tindakan kelas (Classroom Action research). Desain intervensi tindakan/rancangan siklus dalam penelitian ini menggunakan model Kemmis and Mc Taggart, dengan menggunakan sistem spiral yang dimulai dari perencanaan (planning), pelaksanaan (acting), pengamatan (observing), refleksi (reflecting), dan dilanjutkan lagi ke perencanaan kembali (replanning) sebagai dasar untuk strategi pemecahan masalah.

Penelitian tindakan ini dilakukan melalui dua siklus, yang disesuaikan dengan kondisi dan hasil refleksi ketercapaian peningkatan yang diharapkan pada siklus sebelumnya, sesuai dengan tindakan yang dilakukan. Pada siklus pertama belum berhasil, maka dilanjutkan pada siklus berikutnya.

Pada tahap perencanaan tindakan yang meliputi perencanaan umum dan perencanaan khusus. Perencanaan umum meliputi perencanaan waktu pelaksanaan penelitian yang akan dilakukan selama kurang lebih dua 
Peningkatan Hasil Belajar IPA Tentang Ekosistem Yulis Suwandi

bulan. Peneliti mengadakan pertemuan dengan kepala sekolah untuk konsultasi, dan pertemuan dengan rekan sejawat penelti mendiskusikan langkah-langkah pelaksanaan penelitian. Selain itu direncanakan pengaturan kondisi kelas, persiapan materi pelajaran serta media/alat pembelajaran yang diperlukan, pembuiatan kisi-kisi instrumen observasi tindakan, dan kisi-kisi instrumen hasil belajar siswa tentang ekosistem pada pembelajaran hubungan makhluk hidup dalam ekosistem.

Kemudian, peneliti merencanakan tindakan yang akan dilakukan dalam proses pembelajaran. Perencanaan tersebbut meliputi analisis kurikulum terutama pada kompetensi dasar yang akan disampaikan kepada siswa dengan menggunakan PBL. Selanjutnya menyusun rencanapembelajaran (RPP) dengan berpedoman pada kurikulum 2013 untuk menentukan standar kompetensi dan kompetensi dasar, sedangkan untuk indikator pembelajaran menggunakan indikator keterampilan proses sains dasar. Selain itu, peneliti juga menyiapkan media pembelajaran dan membuat instrumen tindakan, pengumpulan data dan menyiapkan soal tes tertulis.

Pelaksanaan tindakan dilakukan sesuai dengan jadwal yang telah ditentukan oleh pihak sekolah. Pembelajaran IPA di SDN 009 Sesayap khususnya kelas V dilakukan sebanyak 2 kali pertemuan dalam seminggu. Satu kali pertemuan dilakukan 2 jam pelajaran, 1 jam pelajaran berlangsung selama 35 menit. Dalam penelitian tindakan dilakukan dalam bentuk siklus.

Intrumen pengumpulan data yang digunakan sebagai bahan penilaian terhadap kegiatan proses dan hasil belajar siswa adalah menggunakan instrumen pengumpulan data yang telah diperasiapkan, seperti tes hasil belajar IPA dan berupa lembar observasi/pengamatan ketika menjalankan metode. Oleh sebab itu teknik penilaian yang digunakan disesuaikan dengan objek yang dinilai dan disesuaikan dengan tujuan penilaian. Untuk menilai aktivitas proses dan hasil belajar siswa, teknik penilaian yang dipergunakan adalah dengan mengumpulkan data dengan menggunakan tes hasil belajar berupa tes soal pilihan ganda dengan empat pilihan yaknia, b, c, dan d, serta lembar penilaian berupa lembar observasi/pengamatan.

Kegiatan observasi melakukan pengamatan terhadap pelaksanaan tindakan dengan menggunakan lembar pengamatan yang telah disiapkan sebelumnya oleh peneliti. Pengamatan tersebut mencakup pengaqmatan selama tindakan siswa dan guru di kelas serta pengamatan dalam keterampilan proses yang dilakukan selama proses pembelajaran berlangsung. 
Peneliti bersama observers melakukan evaluasi terhadap kegiatan siswa dan guru selama melakukan kegiatan pembelajaran. Jika hasil yang didapatkan kurang memuaskan atau belum sesuai dengan yang diharapkan maka peneliti dapat melakukan revisi untuk perbaikan tindakan pada siklus berikutnya.

Selanjutnya pada siklus berikutnya dilaksanakan berdasarkan analisis data hasil observasi, pemaknaan data hasil observasi, penjelasan hasil analisis dan kesimpulan mengenai presentase teratasi atau tidaknya permasalahan dalam pembelajaran, serta faktor-faktor lainnya yang menjadi pertimbangan belum tercapainya target dal;am penelitian ini.

\section{HASIL}

Dilihat dari hasil analaisis data selama tindakan mulai siklus I sampai siklus II terlihat adanya peningkatan dari semua data yang di ambil. Data tes berupa skor pada pembelajaran hubungan makhluk hidup dalam ekosistem mengalami peningkatan, dan hasil analisisnya dapat dilihat pada perkembangan hasil yang dicapai mulai dari siklus I meliputi data hasil observasi yang diperoleh dari lembar observasi tindakan guru dan siswa.

Hasil pada siklus I pertemuan pertama lembar observasi guru dalam pembelajaran PBL mencapai $65 \%$ dan kemudian menjadi 90\%. Hasil pada siklus lembar observasi siswa dalam pembelajaran PBL mencapai 75\% dan kemudian menjadi 90\%. Hasil pada siklus II pertemuan pertama lembar observasi guru dalam pembelajaran PBL mencapai 95\% dan kemudian menjadi 100\%. Hasil pada siklus II pertemuan pertama lembar observasi siswa dalam pembelajaran PBL mencapai 95\% dan kemudian menjadi 100\%. Perbandingan hasil analisis data observasi aktivitas guru dan siswa, secara visual dapat pula disajikan dalam Gambar 1 sebagai Berikut:

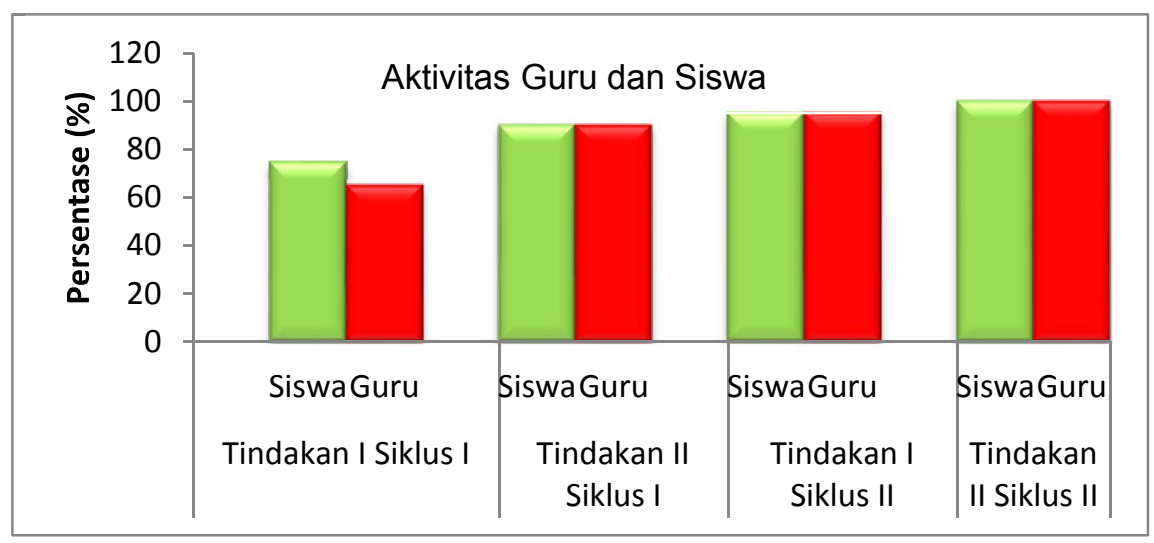

Gambar 1. Perbandingan Aktivitas Guru dan Siswa 
Peningkatan Hasil Belajar IPA Tentang Ekosistem Yulis Suwandi

Peningkatan ini menunjukkan bahwa metode PBL yang diterapkan pada proses pembelajaran ini dapat membuat perubahan yang cukup bagi keberhasilan guru dalam proses pembelajarannya. Tes hasil belajar siswa tentang ekosistem pada pembelajaran hubungan makhluk hidup dalam ekosistem pada siklus I menunjukkan perolehan nilai yang paling banyak pada nilai 50-59, yaitu sebanyak 7 siswa $(23,33 \%)$ selanjutnya dapat dideskripsikan bahwa siswa yang belum tuntas yaitu mendapat nilai yang kurang dari 70 sebanyak 12 siswa (40\%), dikategorikan belum tuntas sedangkan yang mendapatkan nilai di atas 70 sebanyak 18 siswa $(60 \%)$. Distribusi nilai siswa disajikan dalam Tabel 1 berikut ini:

Tabel 1. Distribusi Frekuensi Nilai Hasil

Belajar tentang Ekosistem Pada Pembelajaran Hubungan Makhluk Hidup dalam Ekosistem Siklus I

\begin{tabular}{lccc}
\hline Nilai & F & $\begin{array}{c}\text { Frekuensi } \\
\text { Relatif } \\
(\%)\end{array}$ & $\begin{array}{c}\text { Frekuensi } \\
\text { Komulatif } \\
(\%)\end{array}$ \\
\hline $50-59$ & 7 & 23,33 & 23,33 \\
$60-69$ & 5 & 16,67 & 40 \\
$70-79$ & 9 & 30 & 70 \\
$80-89$ & 5 & 16,5 & 86,5 \\
$90-100$ & 4 & 13,33 & 100 \\
\hline Jumlah & 30 & & \\
\hline
\end{tabular}

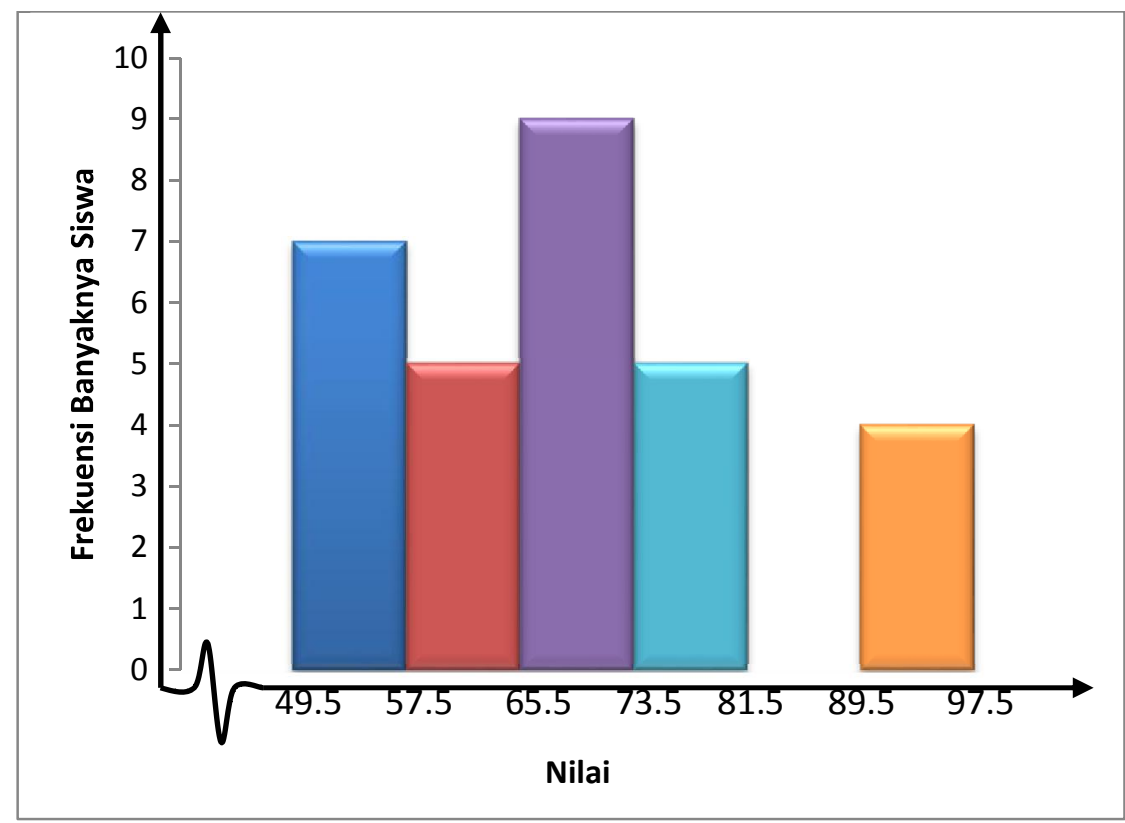

Gambar 2. Nilai Hasil Belajar Siswa Siklus I

Dari hasil analisis di atas, maka disimpulkan bahwa aktivitas guru yang kurang maksimal dalam penerapan metode pembelajaran berbasis masalah (Problem Based Learning), khususnya dalam peningkatan hasil belajar siswa tentang 
ekosistem pada pembelajaran hubungan makhluk hidup dalam ekosistem, secara umum berkaiatan dengan kurangnya penekanan pada fokus masalah yang dibahas, intervensi guru yang kurang memberikan kepada siswa dalam proses pembelajaran untuk merencanakan dan melakukan investigasi, mendemostrasikan hasil belajar serta melakukan Tanya jawab dan refleksi pada akhir pembelajaran. Tetapi dengn perbaiukan yang direncanakan dan dilakukan, maka pada akhir siklus II menunjukkan peningkatan yang berarti.

Peningkatan ini menunjukkan bahwa metode PBL yang diterapkan pada proses pembelajaran ini dapat membuat perubahan yang cukup bagi keberhasilan guru dalam proses pembelajarannya. Tes hasil belajar IPA pada Siklus II yaitu siswa yang belum tuntas y mendapat nilai yang kurang dari 70 sebanyak 3 siswa (13,33\%), dikategorikan belum tuntas sedangkan yang mendapatkan nilai di atas 70 sebanyak 27 siswa $(86,67 \%)$. Hal ini menunjukkan bahwa hasil siklus II mencapai standar minimal yaitu $80 \%$ dari keseluruhan siswa yang mencapai KKM. Distribusi nilai siswa disajikan dalam Tabel 2 berikut ini

Tabel 2. Distribusi Frekuensi Nilai Hasil Belajar Siswa Tentang Ekosistem Pada Pembelajaran Hubungan Makhluk Hidup dalam Ekosistem Siklus II

\begin{tabular}{lccc}
\hline Nilai & $\begin{array}{c}\text { Frekuensi } \\
\text { Absolut }\end{array}$ & $\begin{array}{c}\text { Frekuensi } \\
\text { Relatif (\%) }\end{array}$ & $\begin{array}{c}\text { Frekuensi } \\
\text { Komulatif (\%) }\end{array}$ \\
\hline $50-59$ & 1 & 6,66 & 6,66 \\
$60-69$ & 2 & 6,67 & 13,33 \\
$70-79$ & 9 & 16,67 & 29,99 \\
$80-89$ & 10 & 33,33 & 63,33 \\
$90-100$ & 8 & 36,67 & 100 \\
\hline Jumlah & 30 & & \\
\hline
\end{tabular}

Untuk mendapaat gambaran secara visual mengenai nilai hasil belajar siswa tentang ekosistem pada pembelajaran hubungan makhluk hidup dalam ekosistem pada siklus II, dapat disajiakan dalam bentuk grafik histogram berikut ini pada Gambar 3: 


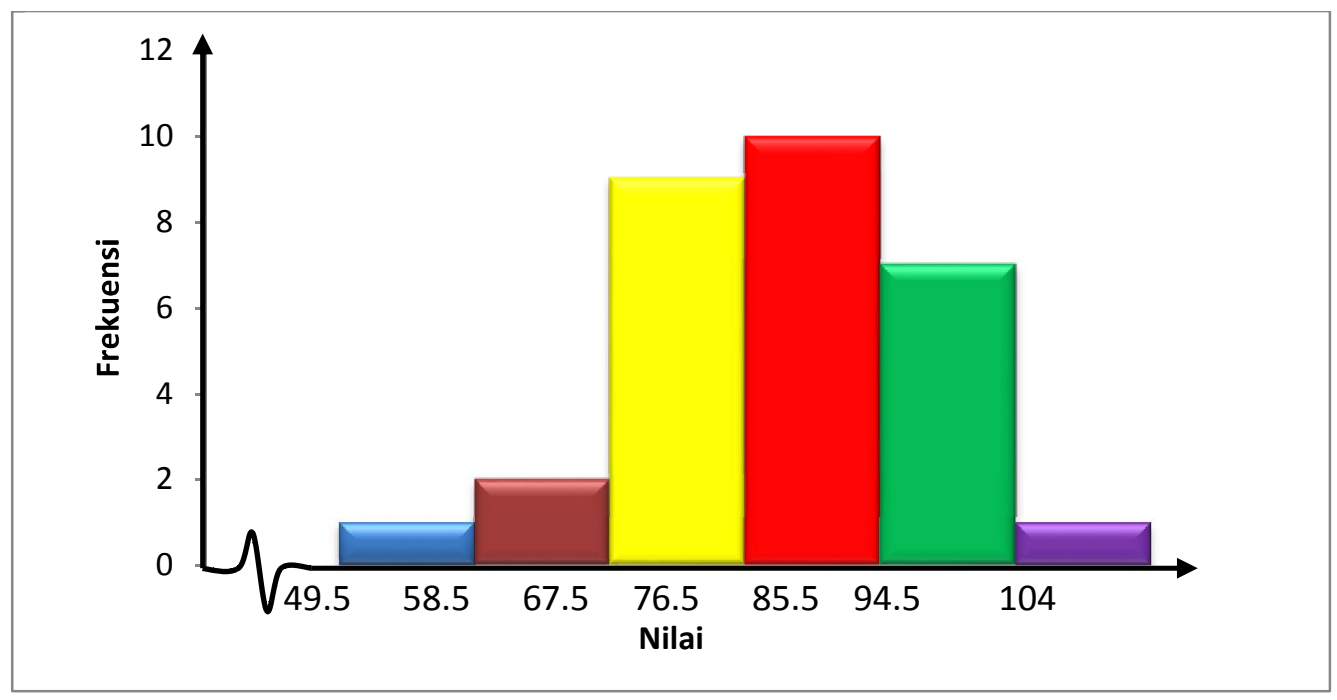

Gambar 2. Nilai Hasil Belajar Siswa Siklus II

\section{PEMBAHASAN}

Dengan demikian hasil belajar IPA meningkat secara signifikan pada siklus II, sebagaimana harapan peneliti telah tercapai, maka penelitian ini tidak dilanjutkan lagi karena telah mencapai hasil yang diharapkan. Hasil belajar IPA yang diperoleh ini di dukung oleh pendapat Amir (2009:21) yang menjelaskan bahwa PBL ini memepersiapkan mahasiswa untuk berpikir kritis dan analitis, dan untuk mencari serta menggunakan sumber pemebalajaran yang sesuai. Lebih lanjut Ngalimun (2009:21) menjelaskan PBL adalah suatu model pembelajaran yang melibatkan siswa untuk memecahkan suatu masalah melalui tahap-tahap metode ilmiah sehingga siswa dapat mempelajari pengetahuan yang berhubungan dengan masalah tersebut dan sekaligus memiliki keterampilan untuk memecahkan masalah.
Dengan demikian, metode PBL dapat menciptakan suasana lingkungan kelas yang kondusif, aktif, kreatif dan menyenangka, serta membentuk kepribadian pada diri siswa.

Hasil penelitian ini juga di dukung oleh temuan Johari (2013: 66-73) hasi penelitian pelaksanaan $\mathrm{PBL}$ dalam proses belajar mereka. Kesimpulannya, PBL adalah strategi pengajaran yang perlu diterapkan dalam proses belajar di lembaga tinggi terhadap pengembangan siswa yang brilian dan terampil.

\section{SIMPULAN}

Berdasarkan hasil analisis data, interpretasi hasil analisis dan pembahasan, maka dapat diambil beberapa kesimpulan sebagai berikut:

Pertama, proses pembelajaran Ilmu Pengetahuan Alam (IPA) di kelas V Sekolah Dasar 009 Sesayap kecamatan Sesayap 
Kabupaten Tana Tidung, khususnya tentang ekosistem pada pembelajaran hubungan makhluk hidup dalam ekosistem melalui metode Problem Based Learning, dapat meningkatkan hasil belajar siswa dan proses pembelajaran yang kondusif, aktif, kreatif dan menyenangkan. Sesuai dengan hasil observasi aktivitas guru dan siswa serta hasil dokumentasi. Maka langkah - langkah pembelajaran dengan menggunakan metode Problem Based Learning yang diterapkan, terus mengalami kemajuan pada setiap siklus. Sehingga pada akhir siklus II proses pembelajaran telah berhasil dan tuntas yaitu telah mencapai $90 \%$.

Kedua, proses pembelajaran dengan menggunakan Problem Based Learning, khususnya tentang ekosistem pada pembelajaran hubungan makhluk hidup dalam ekosistem. Hal ini senada dengan hasil penelitian Annisa (2012) yang menunjukkan bahwa pembelajaran Problem Based Learning (PBL) dapat meningkatkan hasil belajar siswa pada pembelajaran IPA kelas IV SDN Begalon I Surakarta Tahun Pelajaran 2011/2012.

Ketiga, media pembelajaran yang digunakan pada pembelajaran bervariatif yaitu dengan media belajar berupa gambar hewan dan tumbuhan, tulisan pada kertas, kertas berwarna dan LCD. Media pembelajaran yang digunakan dalam PBM ini membantu siswa untuk membangkitkan minat dan kreatifitas dalam meningkatkan hasil belajar IPA pada khususnya.

Keempat, keberhasilan pembelajaran Ilmu Pengetahuan Alam (IPA) di kelas V Sekolah Dasar 009 Sesayap kecamatan Sesayap Kabupaten Tana Tidung,khususnya tentang ekosistem pada pembelajaran hubungan makhluk hidup dalam ekosistem, ditandai dengan peningkatan hasil belajar siswa pada mata pelajaran IPA. Dilihat dari evaluasi siklus I dan siklus II, hasil belajar IPA siswa terus mengalami peningkatan. Peningkatan yang signifikan terjadi pada siklus II, dimana nilai rata - rata kelas telah melampaui KKM yaitu 78 (KKM 70), dengan jumlah siswa yang tuntas mencapai 90\%, yaitu berjumlah 27 orang.

Kelima, peningkatan hasil belajar siswa khususnya tentang ekosistem pada pembelajaran hubungan makhluk hidup dalam ekosistem terutama menekankan pada kemampuan siswa untuk meningkatkan hasil belajar IPA.

Keenam, Peningkatan hasil belajar siswa khususnya tentang ekosistem pada pembelajaran hubungan makhluk hidup dalam ekosistem, juga menekankan pada nilai kepedulian diri siswa khususnya pada hewan dan tumbuhan yang berada di daerah tempat tinggalnya maupun lingkuingan sekolah. Hal ini dimaksudkan untuk membentuk karakter 
Peningkatan Hasil Belajar IPA Tentang Ekosistem Yulis Suwandi

peserta didik menjadi manusia yang memiliki rasa scientist, dimanapun mereka berada. Sehingga dapat meletakkan dasar kecerdasan, pengetahuan, kepribadian, akhlak mulia, serta keterampilan untuk hidup mandiri dan mengikuti pendidikan lebih lanjut.

Berdasarkan paparan temuan di atas, dapat disimpulkan bahwa metode Problem Based Learning dapat meningkatkan hasil belajar IPAkhususnya tentang ekosistem dan membentuk karakter kepedulian di dalam diri siswa khususnya pada hewan dan tumbuhan yang berada di daerah tempat tinggalnya maupun lingkungan sekolah mampu lingkuingan sekolah sehingga manjadikan siswa memiliki rasa scientist di manapun berada.

\section{DAFTAR RUJUKAN}

Abidin, Yunus. 2014. Desain Sistem Pembelajaran Dalam konteks Kurikulum 2013. Bandung: PT Refika Aditama.

Ahmad, Abu, Supatmo. 1998. Ilmu Alamiah Dasar. Jakarta: PT Rineka Cipta.

Amir, M Taufiq. 2009. Inovasi PendidikanMelalui Problem Based learning. Jakarta: Prenada Media Group, 2009.

Asrori, Mohammad. 2012. Penelitian Tindakan Kelas, Bandung: CV Wacana Prima.
Haryono. 2013. Pembelajaran IPA yang Menarik dan Mengasyikkan. Yogyakarta: Kepel Press.

Jihad, Asep, Abdul Haris. 2012. Evaluasi Pembelajaran. Yogyakarta: Multi Pressindo.

Jufri, Wahab. Belajar 2013. Pembelajaran SAINS. Bandung: Pustaka Reka Cipta.

Mulyasari, Annisa Septiyani. 2012. Peningkatan Hasil Belajar IPA Melalui Metode Problem Based Learning (PBL) Materi Gaya Pada Siswa Kelas IV SD Negeri Begalon 1 No 240 Surakarta Tahun Pelajaran 2011/2012.

Ngalimun, Strategi dan Model Pembelajaran. Yogyakarta: Aswaja Pressindo, 2014. Siregar, Eveline, Hartini Nara. 2010. Teori Belajar dan Pembelajaran. Bogor: Ghalia Indonesia.

Surif, Johari, dkk.2013. Implementation of Problem Based Learning in Higher Education institutions and Its Impact on Students' Learning. The 4th International Research Symposium on Problem-Based Learning (IRSPBL): 66-73. 